\title{
Youth Centre As An Activities Space To DeVelop Talents ANd INTERESTS Of TeEnAgers IN SUKOHARJO
}

\author{
Gelanggang Remaja Sebagai Wadah Kegiatan \\ Dalam MENGEMbangkan BaKat Dan Minat REMaja \\ Di SUKOHARJO
}

\author{
Raymond Allen Ghozali ${ }^{*}$, Suparno ${ }^{2}$, Samsudi $^{3}$ \\ Program Studi Arsitektur, Fakultas Teknik, Universitas Sebelas Maret Surakarta ${ }^{1}$ \\ Email : raylengho@gmail.com* \\ Program Studi Arsitektur, Fakultas Teknik, Universitas Sebelas Maret Surakarta ${ }^{2}$ \\ Program Studi Arsitektur, Fakultas Teknik, Universitas Sebelas Maret Surakarta ${ }^{3}$
}

\begin{abstract}
Youth Center is a place to contain activities for teenagers in spare time, to distribute the hobby, to developing talents and interests, to find and meet friends, or sometimes just come because they feel bored. Teenagers can learn a variety of ability or even new ability which previously less or not at all under their control. Generally, the activities in the Youth Center activities include sports, arts, and education. In Indonesia, not all regions have satisfy facilities to accommodate the vairety of teenager' activities. Sukoharjo district, an area located in Central Java, bordering with Surakarta City, is one of the various regions in Indonesia are encountered this problem. The lack of facilities intended for teenagers in Sukoharjo, resulting in their less developed on aspects other than academic, because there is little space for them to learn about other things such as sports and the arts are more complex. Youth Center comes with a variety of facilities that can support a variety of positive activities teenagers. Human resourch in Sukoharjo which are given them a place to develop and explore themselves since teenagers and is expected to create a generation of achievers and can make glory for the name of Sukoharjo.
\end{abstract}

Keywords: Youth Center, Teenager, Sukoharjo, Sports, Arts.

\section{PENDAHULUAN}

Dalam proses pendewasaan diri, setiap orang akan mengalami sebuah masa yang disebut dengan masa remaja. Masa remaja adalah sebuah masa transisi dari masa anakanak menuju masa dewasa. Pada masa ini ditandai dengan perkembangan fisik yang cepat, terutama tinggi dan berat badan, perubahan organ-organ seksual, dan perubahan psikis (Hurlock, 1978).

Masa remaja merupakan masa yang penting dalam perkembangan manusia mulai mencari identitas dalam rangka mempersiapkan diri menghadapi masa dewasa. Pada masa tersebut, remaja cenderung ingin menyalurkan semua keinginannya. Hal tersebut juga didukung oleh pengaruh lingkungan tempat tinggalnya. Penyaluran keinginan yang didukung oleh pengaruh lingkan positif akan membentuk pribadi remaja yang positif, sebaliknya apabila dukungan lingkungan negatif, akan membawa pengaruh negatif pula (Arifah, 2015). Kutipan tersebut diambil dari jurnal arsitektur yang berjudul 
"Youth Center dengan Pendekatan Aristektur Regionalisme di Kabupaten Magelang". Dari kutipan di atas dapat diambil kesimpulan bahwa pada umumnya, masa remaja merupakan masa-masa pencarian jati diri. Pada masa sekarang, para remaja cenderung ingin menyalurkan semua keinginan dalam pemikiran. Oleh karena itu, mereka memerlukan fasilitas untuk mewadahi berbagai kegiatan yang ingin mereka lakukan, dalam rangka mengeksplorasi diri dan menemukan jati diri.

Remaja cenderung lebih suka berkumpul bersama teman-teman sebaya yang mempunyai kesamaan, baik dalam hal minat, pendapat, pemikiran, atau hal-hal lain yang menjadikan mereka nyaman untuk beraktifitas bersama. Mereka cenderung ingin menjadi bagian dari sebuah kelompok untuk kemudian mendapatkan sebuah pengakuan.

Pemberdayaan remaja telah mendapat dukungan dengan adanya UU RI yang menyatakan bahwa setiap anak berhak memperoleh pendidikan dan pengajaran dalam rangka pengembangan pribadinya dan tingkat kecerdasan sesuai dengan minat dan bakatnya (Undang-Undang Republik Indonesia Nomor 23 Tentang Perlindungan Anak, 2002).

Pemuda adalah aset masa depan bangsa. Dalam rangka membangun kepemudaan, maka setiap daerah di masa mendatang mempunyai harapan besar untuk dikelola oleh generasi yang baik (Ismail, 2016). Kutipan tersebut diambil dari jurnal arsitektur berjudul "Youth Centre di Kebumen sebagai Wadah Pengembangan Kreativitas Remaja dengan Pendekatan Psikologi Arsitektur." Di dalam jurnal tersebut dijelaskan bahwa di Kabupaten Kebumen, pemuda dan remaja mengalami kondisi yang cukup memprihatinkan di bidang olahraga dan kebudayaan yang menyebabkan kondisi kepemudaan di Kebumen pengalami penurunan. Sarana dan pra sarana yang minim, keterbatasan tenaga pengajar, kurangnya gedung olahraga dan kesenian yang memadai, dan kelompok kesenian yang kurang terbina menjadi suatu masalah bagi pemuda dan remaja di Kebumen. Hal-hal inilah yang kurang lebih juga dialami oleh para remaja di Sukoharjo, dimana mereka membutuhkan dukungan dalam mengembangkan diri mereka.

Masa remaja merupakan masa yang sangat penting dalam perkembangan hidup seorang manusia. Pada masa inilah seseorang mulai menemukan jati diri untuk kemudian menentukan arah hidupnya. Saat ini, di Sukoharjo para remaja masih kurang dimanjakan oleh fasilitas-fasilitas penunjang yang dikhususkan untuk pengembangan diri mereka. Wadah bagi remaja di Sukoharjo massih belum mencukupi, sehingga mengakibatkan sebagian besar hanya menghabiskan masa remaja mereka dengan sekolah dan lalu pulang ke rumah.

Sukoharjo perlu menyediakan lebih banyak wadah untuk memfasilitasi para warga khusus remaja, agar dapat lebih baik dalam mengembangkan potensi-potensi sumber daya manusia yang dimiliki, yang apabila mereka berprestasi tentu akan membawa dan mengharumkan nama Sukoharjo itu sendiri.

Salah satu cara dalam menjawab kebutuhan tersebut adalah dengan menyediakan fasilitas terpadu yang dapat digunakan para remaja di Sukoharjo menyalurkan bakat dan minat mereka. Manfaat lain yang bisa didapatkan ialah akan tercipta suatu lingkungan positif bagi remaja, sehingga dapat mengarahkan perkembangan psikis mereka ke arah yang lebih baik.

Perancangan Gelanggang Remaja di Sukoharjo bertujuan untuk mewadahi berbagai kegiatan dalam rangka perkembangan diri remaja agar mereka mampu bereksplorasi, menemukan jati diri, untuk kemudian mengasah minat dan bakat yang mereka miliki, serta menyediakan ruang bagi para remaja untuk bersosialisasi.

\section{METODE}

Metode desain yang digunakan dalam proses perencanaan dan perancangan Gelanggang Remaja meliputi beberapa tahapan, yaitu : 
1. Eksplorasi

Tahap ini bertujuan mencari ide-ide dan gagasan-gagasan melalui fenomenafenomena yang terjadi di masyarakat maupun di lingkungan tertentu.

a. Fenomena Remaja

a) Masa remaja adalah masa pencarian jati diri.

b) Remaja cenderung ingin menyalurkan semua keinginannya.

c) Lingkungan sekitar sangat berpengaruh dalam perkembangan remaja.

d) Remaja cenderung memiliki suasana hati yang labil.

e) Remaja cenderung menyukai berkumpul bersama teman-teman seumurannya yang memiliki kesamaan minat.

b. Fenomena Remaja di Sukoharjo

a) Pada tahun 2016 terdapat sekitar 205.042 remaja di Sukoharjo (www.sukoharjokab.go.id).

b) Remaja Sukoharjo beberapa kali memenangi perlombaan tingkat provinsi maupun nasional.

c) Minimnya fasilitas pengembangan diri bagi remaja di Sukoharjo.

d) Belum ada suatu wadah terpadu untuk kegiatan-kegiatan remaja yang positif di Sukoharjo.

2. Identifikasi Masalah

Merupakan tahapan awal dalam pemrograman Gelanggang Remaja berupa proses identifikasi permasalahan dan kegiatan. Tahapan meliputi :

a. Mengidentifikasi permasalahan pokok, yakni kebutuhan remaja untuk melakukan kegiatan di luar kegiatan sekolah dengan memperhatikan dampak positifnya bagi mereka.

b. Mempelajari informasi yang relevan, yang diperlukan dalam proses pemrograman. Penulis melakukan studi kasus terhadap obyek rancang bangun yang sejenis sehingga dapat memberikan informasi tambahan yang dapat membantu tahapan pemrograman. c. Mengidentifikasi kebutuhan calon pelaku kegiatan Gelanggang Remaja.

d. Mengidentifikasi karakteristik Kabupaten Sukoharjo sebagai lokasi Gelanggang Remaja.

3. Identifikasi Fungsi Obyek Rancang Bangun

Pemrograman fungsional merupakan tahapan yang yang mengidentifikasi halhal yang berkaitan dengan fungsi dan kegiatan di dalam Gelanggang Remaja, meliputi :

a. Identifikasi visi dan misi Gelanggang Remaja.

b. Identifikasi struktur organisasi pengelolaan Gelanggang Remaja.

c. Identifikasi area kegiatan Gelanggang Remaja.

d. Identifikasi kegiatan pelaku di dalam Gelanggang Remaja.

e. Strukturisasi kegiatan-kegiatan di dalam Gelanggang Remaja.

4. Architectural Programming Proses meliputi 4 bagian, yaitu :

a. Analisis persyaratan ruang untuk meningkatkan kualitas penggunaan ruang-ruang kegiatan Gelanggang Remaja secara optimal,

b. Analisis pembentukan massa Gelanggang Remaja.

c. Analisis tapak, meliputi :

a) Analisis lokasi Kabupaten Sukoharjo dan persyaratan tapak di Kabupaten Sukoharjo.

b) Analisis tapak terpilih, merupakan tinjauan dan evaluasi karakteristik di dalam dan sekitar tapak.

5. Perancangan Arsitektural

Tahapan ini merupakan tahap untuk mengembangkan skema desain Gelanggang Remaja yang didapatkan dari proses pemrograman yang telah dilakukan.

\section{HASIL DAN PEMBAHASAN}

\subsection{Peran Dan Fungsi}

Pentingnya peranan sarana prasarana/ fasilitas yang memadai menjadi pemicu 
tumbuh dan berkembangnya minat dan bakat seseorang. Untuk sebagian kalangan remaja, kegiatan di luar pendidikan akademik lebih menyenangkan daripada kegiatan belajar formal di sekolah. Remaja yang memiliki minat dan bakat di bidang seni dan olahraga tentu ingin mendapatkan fasilitas yang memadai dalam menunjang kegiatan. Disinilah peran Gelanggang Remaja muncul sebagai tempat yang mewadahi pengembangan bakat dan minat remaja di Sukoharjo. Peran Gelanggang Remaja ini lebih ditekankan pada :

a. Sebagai sarana pengembangan bakat dan minat remaja.

b. Sebagai wadah untuk menuangkan ekspresi

c. Sebagai sarana rekreasi dan hiburan.

d. Mendukung aspek pemberdayaan remaja.

e. Meningkatkan kualitas remaja.

f. Meningkatkan interaksi sosial masyarakat, terutama remaja.

Adapun fungsi dari Gelanggang Remaja yang direncanakan adalah :

a. Sebagai sarana pengembangan bakat dan minat remaja

Tersedia fasilitas-fasilitas kesenian dan olahraga untuk menunjang kegiatankegiatan yang direncanakan. Dibedakan menjadi fasilitas yang hanya digunakan untuk berlatih saja dan yang digunakan untuk kejuaraan.

b. Sebagai sarana rekreasi dan hiburan Kegiatan-kegiatan seni dan olahraga dapat menjadi aktifitas rekreasi yang menyenangkan. Menyediakan ruang dan mengadakan event-event tertentu seperti pentas seni, pameran, dan event-event kejuaraan sebagai hiburan untuk publik.

c. Sebagai sarana pemberdayaan remaja Pemberdayaan remaja dilakukan dengan menyediakan fasilitas-fasilitas pelatihan ketrampilan.

\subsection{Pemilihan Tapak}

Dasar Pertimbangan :

a. Tapak terletak di kawasan Kecamatan Sukoharjo, bukan merupakan kawasan lindung dan bisa didirikan bangunan sesuai dengan peraturan pemerintah. b. Tapak terletak di kawasan yang dapat digunakan untuk kegiatan olahraga, seni, serta pendidikan.

c. Akses menuju lokasi mudah dijangkau baik dengan kendaraan umum maupun dengan kendaraan pribadi.

d. Memiliki potensi yang dapat mendukung perkembangan Gelanggang Remaja.

e. Lokasi tapak berada dalam jangkauan infrastruktur kota.

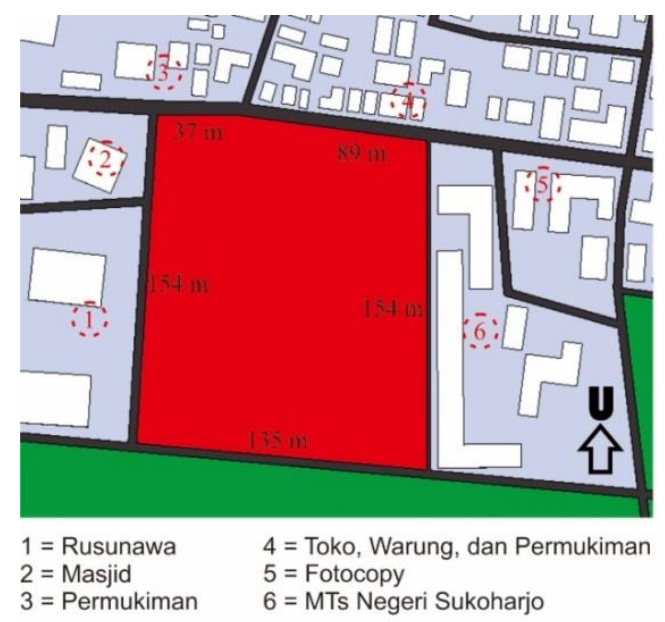

Gambar 1. Lokasi Tapak Terpilih.

Berdasarkan dasar pertimbangan tersebut maka lokasi terpilih terletak di Jalan Agus Salim, Kelurahan Joho, Kecamatan Sukoharjo. Gambar 1 menunjukkan eksisting lokasi tapak terpilih yang berbatasan pada sisi barat berupa rusunawa dan masjid, sisi utara berupa permukiman, sisi timur berupa MTs Negeri Sukoharjo, dan sisi selatan berupa sawah.

\subsection{Pencapaian}

\section{Tujuan :}

Mendapatkan lokasi main entrance dan side entrance pada tapak yang sesuai dengan kebutuhan.

\section{Dasar pertimbangan Main Entrance :}

a. Menghadap langsung ke jalan utama agar memudahkan sirkulasi masuk dan keluar tapak.

b. Mudah dikenali dan mudah dicapai.

c. Keamanan dan kenyamanan dalam pencapaian.

d. Mampu mengarahkan pengunjung ke dalam tapak.

\section{Dasar pertimbangan Side Entrance :}


a. Keamanan, kenyamanan, dan kemudahan dalam pencapaian.

b. Mendukung fungsi kegiatan bagi pengelola.

c. Tidak mengganggu sirkulasi kegiatan utama.

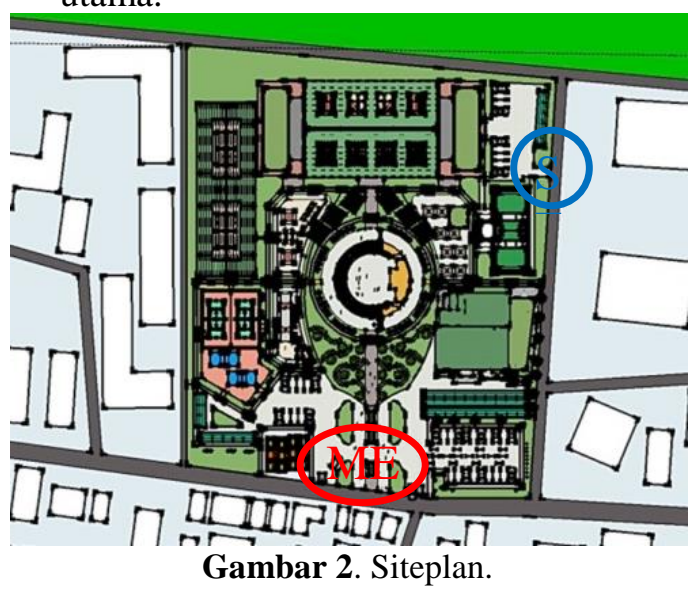

Seperti terlihat pada gambar 2, main entrance diletakkan pada sisi jalan utama yakni jalan Agus Salim karena mudah dilihat dan dicapai, sedangkan side entrance yang diperuntukkan bagi pengelola diletakkan pada sisi jalan di sisi samping timur agar tidak menganggu pencapaian pengunjung.

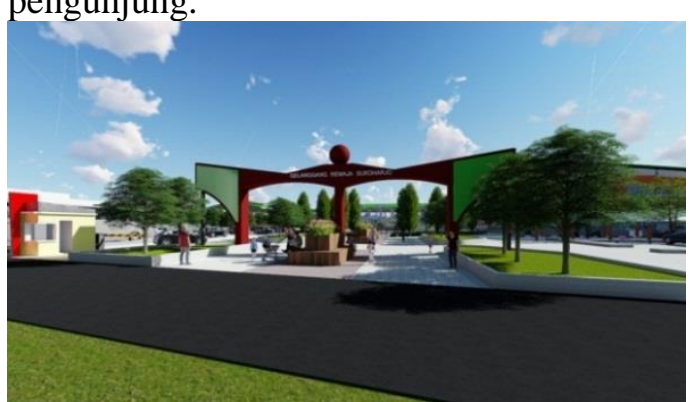

Gambar 3. Gerbang masuk.

Pada gambar 3 di atas adalah main entrance yang digunakan sebagai jalur utama keluar masuk tapak. Main entrance dilengkapi dengan gapura untuk memperkuat kesan dan tampilan. Entrance utama dapat digunakan langsung sebagai jalur keluar masuk pengunjung dengan berjalan kaki seperti terlihat pada gambar 4 . Jalur sirkulasi setelah gapura didesain agar mampu mengarahkan pengunjung ke berbagai zona kegiatan di dalam tapak. Di jalur pengunjung mempunyai area pandangan yang luas sehingga dapat melihat ruang-ruang kegiatan dan bangunan yang tersebar di dalam tapak.

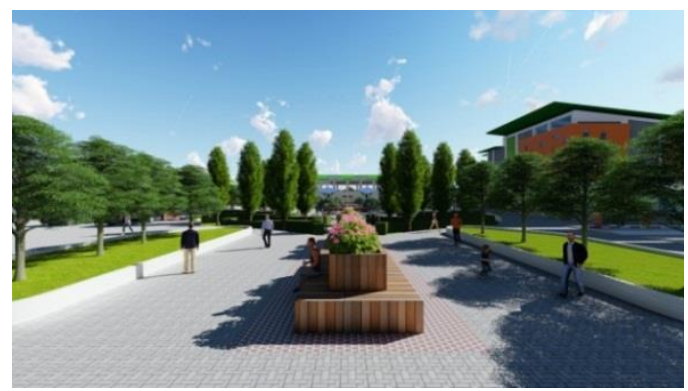

Gambar 4. Main Entrance.

\subsection{Kegiatan}

Berdasarkan peran dan fungsi, secara garis besar kegiatan utama dalam Gelanggang Remaja dikelompokkan menjadi :

a. Kegiatan utama

Kegiatan yang menjadi fokus utama dalam memfasilitasi para remaja, khusus dalam mengembangkan bakat dan minat mereka.

1) Kegiatan Seni

Kegiatan yang berhubungan dengan seni musik, seni lukis, seni tari..

2) Kegiatan Olahraga

Kegiatan yang berhubungan dengan olahraga baik olahraga indoor maupun outdoor.

3) Kegiatan Kepustakaan

Kegiatan yang meliputi kegiatan membaca di ruang pustaka dengan berbagai koleksi buku disertai dengan kegiatan-kegiatan penunjang seperti berselancar internet,

b. Kegiatan penunjang

Kegiatan yang menunjang berlangsung kegiatan utama yakni kegiatan klub/ komunitas, kursus, mengobrol, dll.

c. Kegiatan insidensial

Kegiatan yang hanya diadakan di waktuwaktu tertentu dan hanya bersifat sementara. Kegiatan dapat berupa :
1) Pentas seni
2) Pameran karya
3) Event-event kejuaraan

d. Kegiatan pengelolaan

Kegiatan yang dilakukan pengelola untuk memfasilitasi kegiatan-kegiatan 
utama dan kegiatan-kegiatan penunjang, seperti administrasi, tata kelola keuangan, dll.

e. Kegiatan servis

Toilet, makan, minum, sholat, dll.

\subsection{Pelaku Kegiatan}

Gelanggang Remaja merupakan obyek yang digunakan oleh beberapa macam pelaku kegiatan. Secara garis besar dapat dilihat pada bagan 1 berikut.

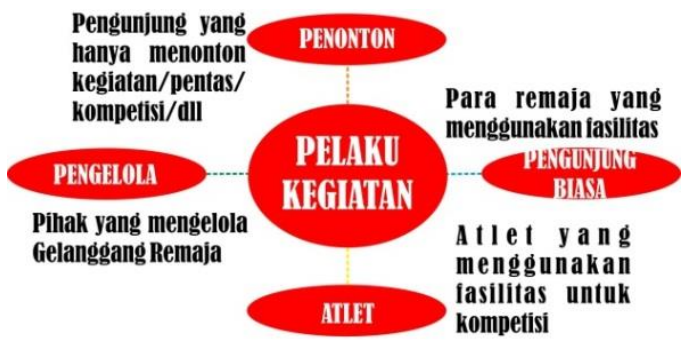

Bagan 1. Pelaku Kegiatan.

Pelaku kegiatan utama adalah remaja. Para remaja dapat berkunjung sebagai pengunjung biasa, penonton, dan sebagai atlet yang berlatih. Pelaku kegiatan yang datang sebagai atlet, akan menerima pelatihan dari instruktur yang disediakan dan memperoleh keutamaan dalam mempergunakan ruang kegiatan. Pengelola bertugas untuk mengelola berbagai kegiatan di dalam Gelanggang Remaja agar terselenggara. Pengelola terdiri dari bagian operasional, tata usaha, humas, dan tenaga pendukung.

\subsection{Penyebaran Massa}

Gelanggang Remaja adalah obyek yang memiliki berbagai macam kegiatan di dalam. Kegiatan-kegiatan tersebut kemudian tersebar ke dalam zona-zona kegiatan yakni kegiatan penerimaan, kesenian, olahraga, kepustakaan, pengelolaan, dan servis. Ide dasar dalam meletakkan ruang-ruang kegiatan di dalam tapak adalah dengan meletakkan open space sebagai zona pengikat, untuk berbagai zona kegiatan yang kemudian diikuti oleh penyebaran massa yang mengelilingi open space tersebut. Untuk lebih jelasnya dapat dilihat pada gambar 5 dan gambar 6, arah penataan massa memusat.

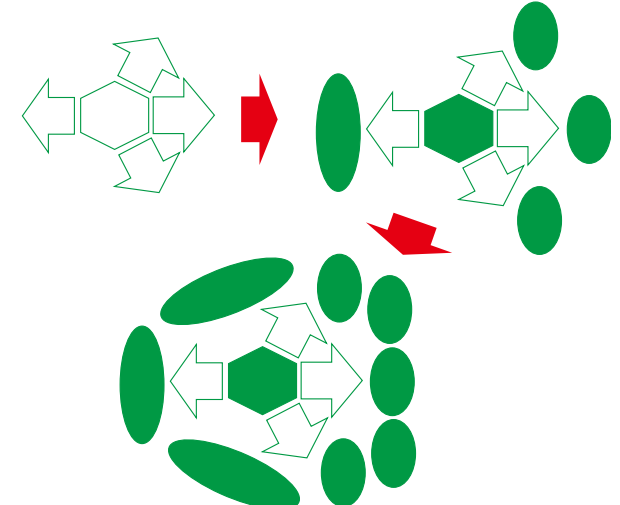

Gambar 5. Skema penyebaran massa.

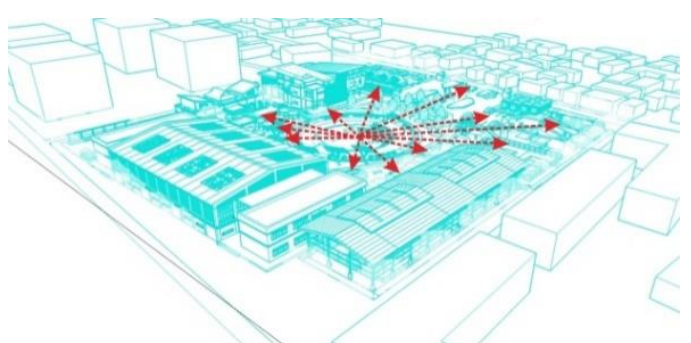

Gambar 6. Perspektif penyebaran massa.

Open space yang berperan sebagai zona pengikat antar kegiatan ini dapat difungsikan sebagai panggung outdoor, mengobrol, ataupun sebagai ruang komunal.

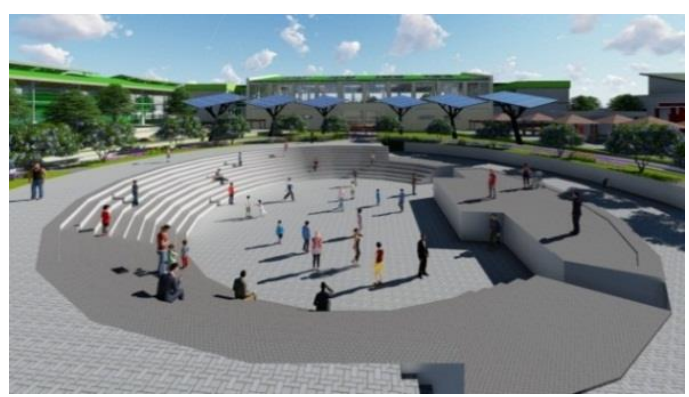

Gambar 7. Zona pengikat / open space.

Berikut ini dapat dilihat pada gambar 8 adalah peta persebaran massa dari berbagai kegiatan di dalam tapak.

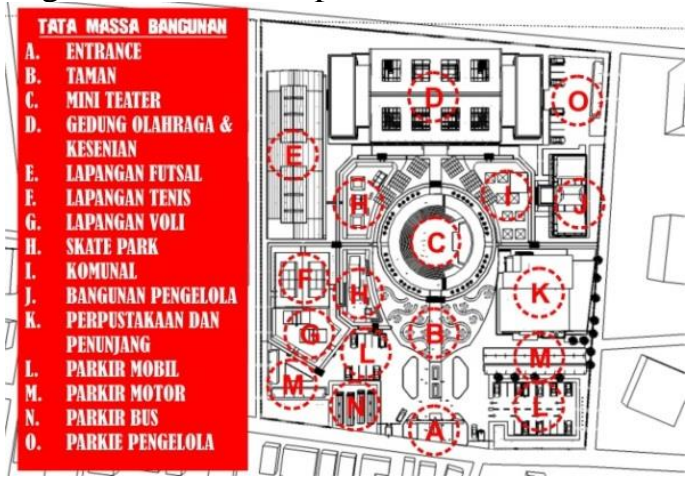

Gambar 8. Peta persebaran massa. 
Pada gambar 9 dapat dilihat visualisasi penampakan Gelanggang Remaja di antara bangunan-bangunan sekitar. Gelanggang Remaja didesain dengan menyediakan banyak ruang sebagai ruang kegiatan outdoor di area tengah dan dekat jalur entrance, sedangkan massa-massa bangunan diletakkan menyebar di area sisi dari tapak.

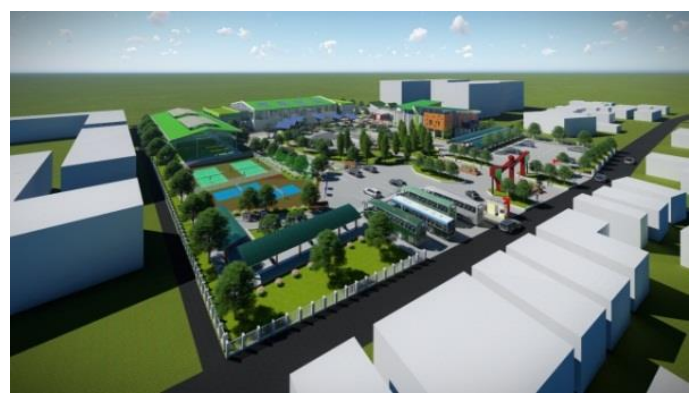

Gambar 9. Perspektif Gelanggang Remaja.

\subsection{Peruangan}

Gelanggang Remaja terdiri dari kegiatan-kegiatan di dalam bangunan dan kegiatan-kegiatan di luar bangunan. Kegiatan-kegiatan yang dilakukan di dalam bangunan adalah kegiatan kesenian, kegiatan kepustakaan, sebagian kegiatan olahraga, serta kegiatan pendukung dan servis.

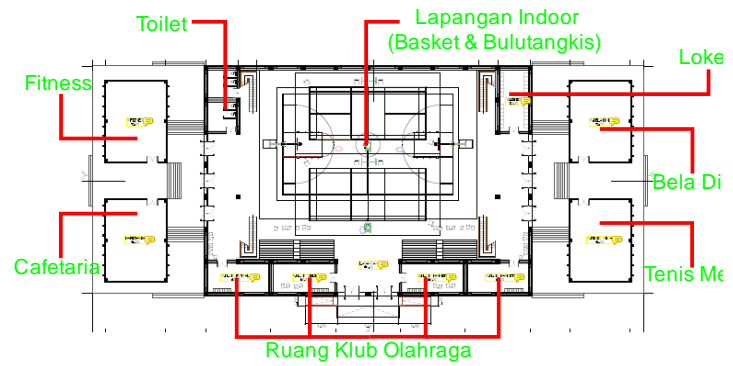

Gambar 10. Skema denah ruang olahraga.

Pada gambar 10 dapat dilihat denah peruangan pada bangunan olahraga. Ruangan utama dengan luasan terbesar pada bangunan adalah area lapangan basket, dimana dilengkapi dengan tribun penonton. Ruang-ruang yang digunakan sebagai ruangan utuk klub ataupun atlet olahraga disediakan juga di lantai 1. Di kedua sisi samping bangunan adalah ruangan untuk kegiatan olahraga lainnya yakni tenis meja, bela diri, fitness, dan juga dilengkapi kafetaria sebagai fasilitas pendukung.

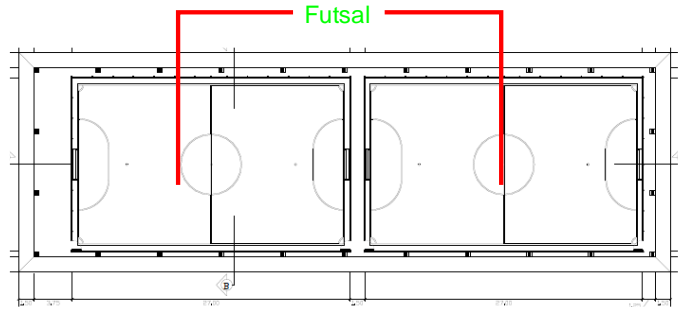

Gambar 11. Skema denah bangunan futsal.

Terdapat bangunan olahraga lain yang terpisah dari bangunan olahraga utama. Bangunan ini diperuntukkan untuk olahraga futsal, dengan menyediakan 2 lapangan di dalam. Pemisahan bangunan bertujuan untuk memberikan ruang tersendiri pada olahraga ini, karena merupakan kegiatan dengan jumlah peminat yang banyak dan digunakan baik oleh pengunjung biasa maupun atlet. Denah dari bangunan ini dapat dilihat pada gambar 11.

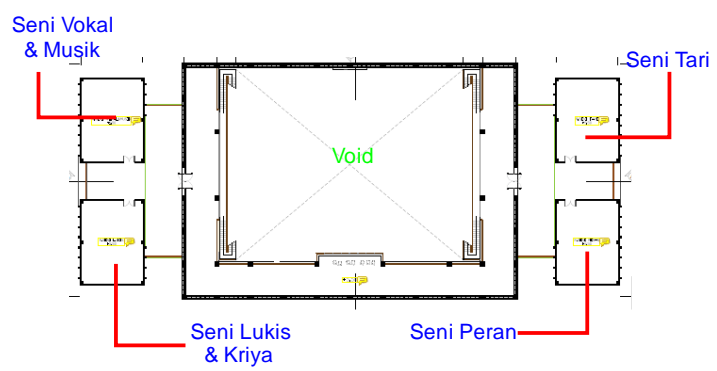

Gambar 12. Skema denah ruang kesenian.

Ruang-ruang kegiatan kesenian, dapat dilihat pada gambar 12, diletakkan pada bangunan utama bersama ruang-ruang olahraga. Ruang-ruang kegiatan diletakkan di lantai 2 untuk memisahkan dengan ruang kegiatan olahraga serta untuk memperkuat privasi ruang.

Gedung pustaka memiliki 3 lantai dimana lantai 1 berisi ruan-ruang kegiatan penerimaan, administrasi, kafetaria, ruang sholat, dan toilet. Peruangan lantai 1 dapat dilihat pada gambar 13 . 


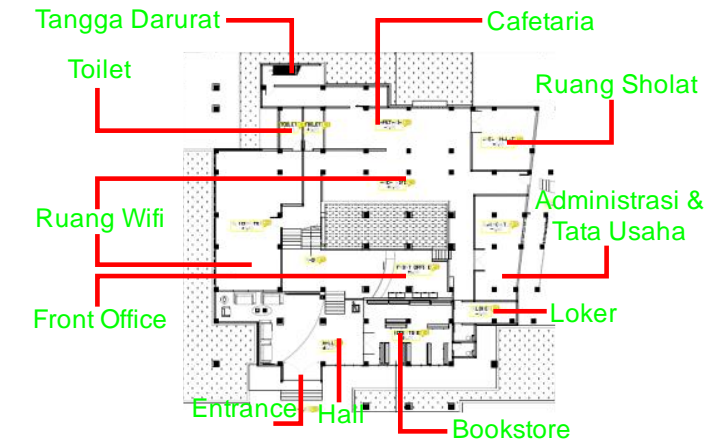

Gambar 13. Skema denah gedung pustaka lt. 1.

Pada lantai 2 Gedung Pustaka berisi ruang-ruang kegiatan utama, yaitu Ruang baca, ruang koleksi, ruang loker, ruang informasi, ruang sholat, dan toilet. Peruangan lantai 2 dapat dilihat pada gambar 14.

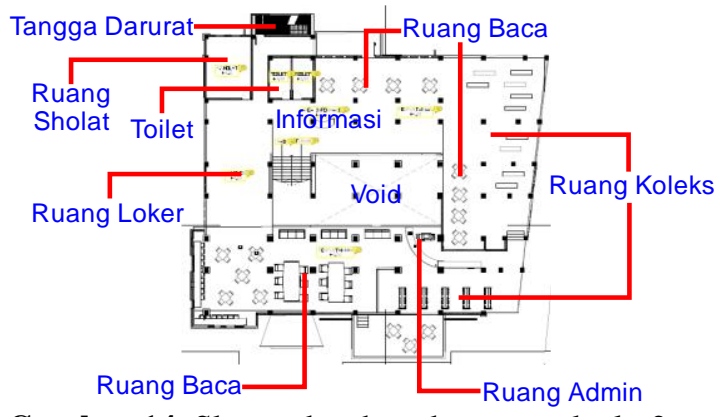

Gambar 14. Skema denah gedung pustaka lt. 2.

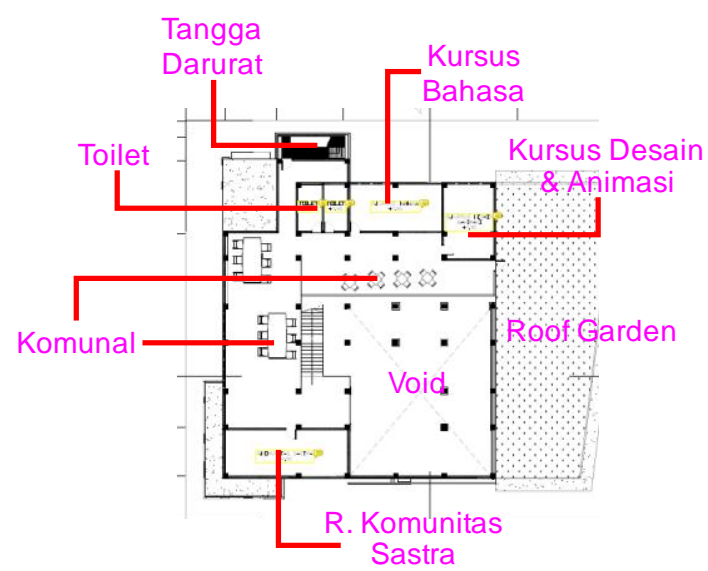

Gambar 15. Skema denah gedung pustaka lt. 3 .

Pada lantai 3 Gedung Pustaka berisikan ruang-ruang kegiatan pendukung yaitu ruang untuk kegiatan pelatihan/ kursus, ruang komunitas sastra, ruang komunal, toilet, dan roof garden. Peruangan lantai 3 dapat dilihat pada gambar 15 .

\subsection{Lansekap \\ Dasar Pertimbangan :}

a. Tata lansekap Gelanggang Remaja sebagai cara dalam memperindah estetika arsitektur, dengan tujuan menarik minat para calon pelaku kegiatan.

b. Tata lansekap dapat mempengaruhi sirkulasi manusia dan udara, serta sebagai cara dalam mempengaruhi penghawaan.

c. Tata lansekap dapat berfungsi untuk memberikan peneduhan pada area tertentu. dan dapat menjadi barrier yang menahan angin kencang dan menyaring debu.

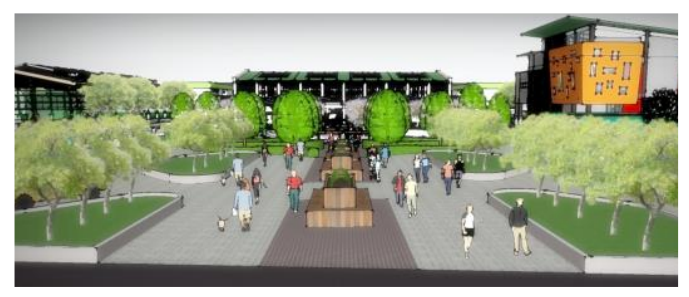

Gambar 16. Lansekap 1.

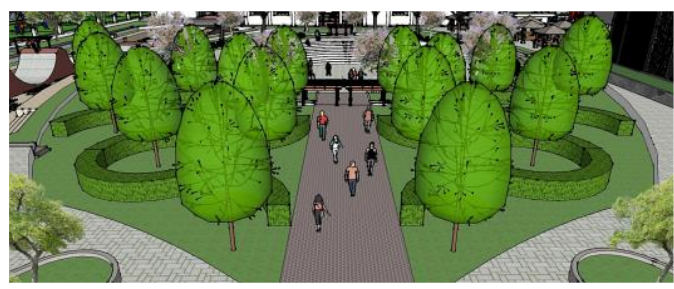

Gambar 17. Lansekap 2.

Tata lansekap didesain dengan penggunaan vegetasi di dalam lingkungan tapak, untuk menciptakan iklim mikro kawasan yang sejuk. Manfaat vegetasi untuk mereduksi panas yang diterima dari sinar matahari dengan menyerap $\mathrm{CO}^{2}$ dan mengeluarkan $\mathrm{O}^{2}$. Vegetasi diletakkan di berbagai sudut yang diperlukan untuk mendukung kegiatan-kegiatan di dalam tapak agar mendapatkan penghawaan yang baik, dan di beberapa area juga berfungsi sebagai barrier angin, debu, ataupun suara. Pada gambar 16 merupakan visualisasi lansekap pada area sekitar jalur entrance Gelanggang Remaja, sedangkan pada gambar 17 merupakan visualisasi lansekap pada area setelah jalur entrance.

\subsection{Perspektif}

Pada gambar 18 dapat dilihat visualisasi dari Gelanggang Remaja dari sisi samping. Calon pengunjung dapat melihat 
area parkir sepada motor dan bangunan Gedung Pustaka dari arah samping.

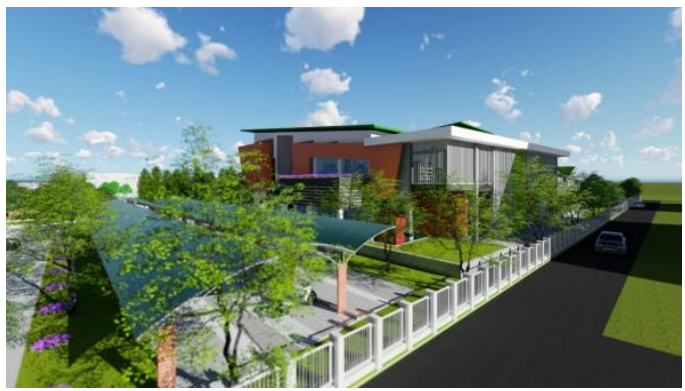

Gambar 18. Perspektif samping Gelanggang Remaja.

Berikut ini pada gambar 19 adalah gedung pustaka yang merupakan salah satu kegiatan utama di dalam Gelanggang Remaja. Eksterior dari bangunan didesain dengan warna cerah dan memberikan beberapa aksen, untuk memberikan kesan bangunan yang atraktif yang diperuntukkan bagi remaja.

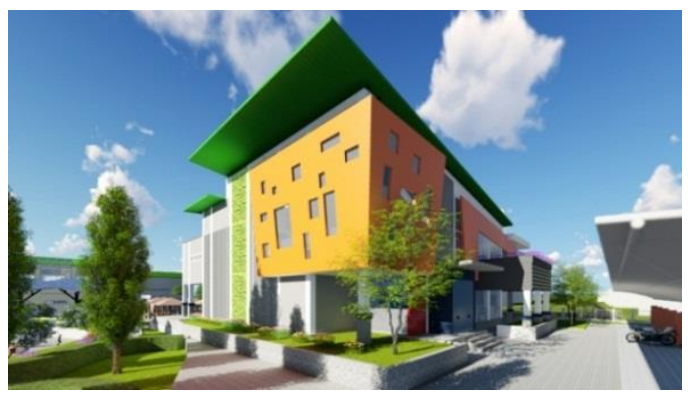

Gambar 19. Perspektif Eksterior Perpustakaan.

Suasana dari ruang baca dapat dilihat pada gambar 20. Ruang baca didesain dengan menempatkan banyak meja dan kursi untuk calon pengunjung agar dapat mewadahi jumlah calon pengunjung. Ruangan cukup luas agar pengunjung dapat dengan nyaman beraktivitas di dalam ruangan.

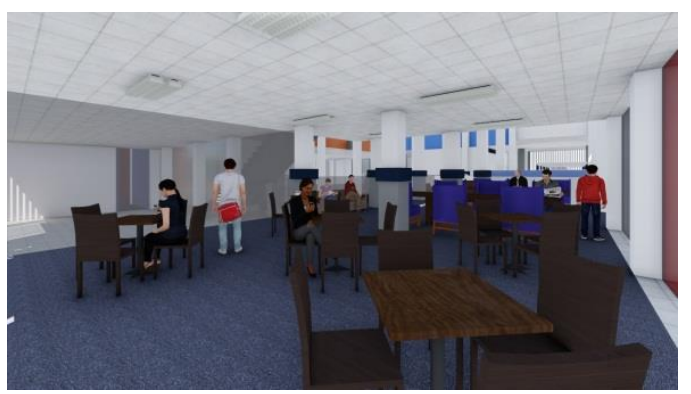

Gambar 20. Ruang baca.
Pada gambar 21 merupakan visualisasi interior dari ruang kegiatan olahraga basket, sedangkan pada gambar 22 merupakan visualisasi interior dari ruang kegiatan olahraga futsal. Kedua ruangan didesain dengan memberikan pencahayaan alami yang cukup sebagai cara untuk melakukan efesiensi energi. Penghawaan ruang dilakukan dengan memberikan bukaanbukaan udara yang mengelilingi area kegiatan.

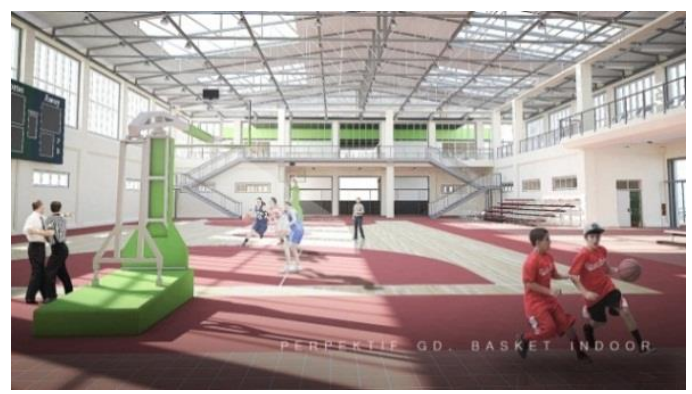

Gambar 21. Lapangan basket.

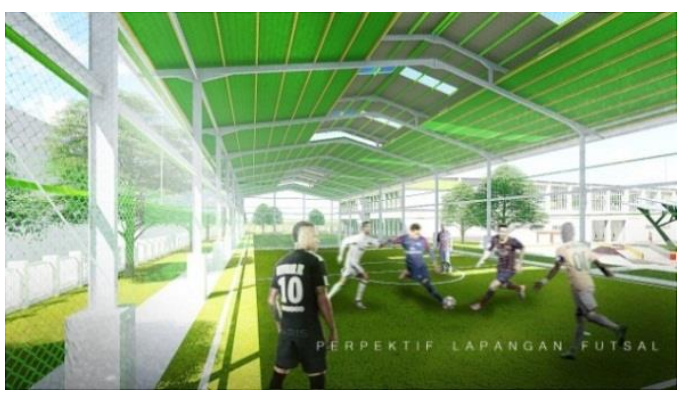

Gambar 22. Lapangan futsal.

Selain lapangan olahraga di dalam bangunan, Gelanggang Remaja juga menyediakan lapangan olahraga di luar bangunan, yaitu lapangan tenis, lapangan voly, dan area skate. Visualisasi lapangan tenis dapat dilihat pada gambar 23, sedangkan visualisasi area skate dapat dilihat pada gambar 24 .

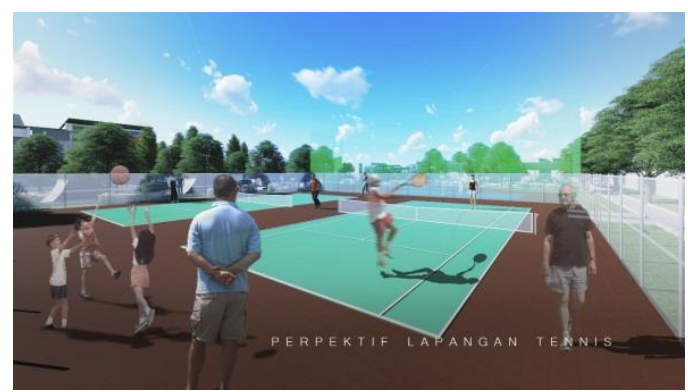

Gambar 23. Lapangan tenis. 


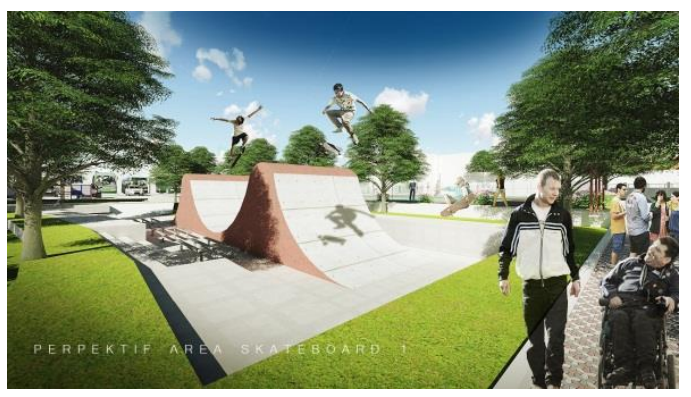

Gambar 24. Area skate.

\section{KESIMPULAN}

Permasalahan arsitektural dari perancangan Gelanggang Remaja sebagai wadah kegiatan remaja di Sukoharjo adalah Gelanggang Remaja membutuhkan banyak ruang-ruang kegiatan, yang ditujukan bagi remaja dalam rangka mengembangkan bakat dan minat mereka, dengan ditunjang oleh sarana-sarana pendukung lain. Ruang-ruang kegiatan tersebut kemudian perlu penataan yang tepat di dalam lingkungan tapak agar setiap kegiatan dapat bekerja secara optimal. Aspek kenyamanan menjadi hal yang perlu diperhatikan agar kegiatan-kegiatan tersebut dapat berjalan secara optimal.

\section{REFERENSI}

Arifah, R. A. (2015). Youth Centre dengan Pendekatan Arsitektur Regionalisme di Kabupaten Magelang. Jurnal Arsitektur dan Lingkungan Binaan UNS.

Hurlock, E. (1978). Perkembangan Anak. Jakarta: Erlangga.

Ismail, F. (2016). Youth Center di Kebumen sebagai Wadah Pengembangan Kreativitas Remaja dengan Pendekatan Arsitektur Psikologi. Jurnal Arsitektur dan Lingkungan Binaan UNS.

(2002). Undang-Undang Republik Indonesia Nomor 23 Tentang Perlindungan Anak. Jakarta: Sekretariat Kabinet RI.

www.sukoharjokab.go.id. 